\title{
Yield performance of commercialized upland fish farms in Ondo state of Nigeria
}

\author{
T. E. Mafimisebi
} Department of Agricultural Economicy and Farm Management. University of Ibadan,Ibailan,
Nigeria

\begin{abstract}
The study examined the socio-demographic characteristics of fish farmers, evaluated the profitability of upland fish farms in the study area and determined the key variahles to which profitability is responsive. Eimpirical results showed that majority of the fish farms came into business less than ten years ago while $62.0 \%$ of the managers of the fish farms had formal education. The total farm size of the twenty-two fish farmv surveyed was $229,112 \mathrm{~m}^{2}$ and the average size of a fish pond unit was $1,80 \mathrm{~mm}^{2}$. Table fish production was preponderant over fingerlings production. About $70.0 \%$ of the fish farms practiscd monoculture, $23.33 \%$ used polvaltural method and 6.6796 emploved both. The major fish species commonly cultured were Tilapia, Alestes, Heterotis and Catfish. The fixed cust per hectare of fish farm for the period studied was AS17,591,48 while wariable cost stood at A2, 053,506.68. The mest imperiant components of fixed costs were labour (41.0295), bore-hole and uater pumps 22.1095 and land and pond construction (14.5095). For variable cost, the most expensive items were fish feeds (51.4456). fish seeds (17.30\%) and transportation and fuel (13, 16\%).

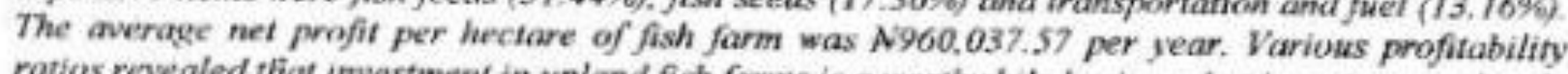
ratios revealed thiat imvestment in upland fish farms is a worthwhile business but imvestors need to do something abowt the fluctuating trends of some of the indices since the dexirable trend is either a consistent increase or decrease. A sensitivity analysis carried out showed that pnofitability is mone responsive to the unit price of fish compared with cost of inputs. The NPV, BI' and IRR were A1.571.710 $15,1.53$ and $52.4 \%$ respectively. The three indicators attest to the fact that fish culture is very profitable in the study area. It is recommended that she various governmenis make access to land and imvestible finds at affordable rates a priority in the study area. Thene is also the need for the establishment of a modern hatchery which will supply fingerlings to fish farmers at subsidized rate.
\end{abstract}

Keywords: Yicld performance, fixed and variable costs, gross revenue, upland fish farms, Ondo State.

\section{Introduction}

In Nigeria in particular and Africa in gencral. nutritionists are extremely worried about the uncomfortably low lcvel of readily available and affordable animal protein sources. This worry is justifiable because the per caput animal protein consamed per day in the continent falts below the recommended quantity of 35.0 gramunes. The level achieved in Africa, West Africa and Nigeria are respectively 12.82, 10.00 and 7.00 grammes (World Bank, 1996, Olayemi. 1996). The main sources of animal protein in Nigeria includes beef, chicken, goat meat, eggs, fish and recently rabbit. Of all these sources of 
animal protein, fish bas the highest level of easily metabolisable proteins. It is also reputed for its high quality caiorics, fat, vitamins, calcium, iron and essential amino acids (Olayide et al, 1981, Tobor, 1990). A causal observation in the market shows that fish is the cheapest of all protein sources (Adewale, 1985. Geoff, and Bennet, 1995) and it is widely consumed across all income groups. The wide acceptability of fish may be owing to the fact that no religious taboos exist against its consumption in Nigeria.
Owing to its cheapness, high nutritional values and wide acceptability, fish has the potential to play an indispensable role in alleviating the pervasive protein malnutrition problem in Africa - a region where high carbohydrate diets are popular. If the seemingly formidable, hydraheaded probiem of protein malnntrition with its adverse effects on health, mental capacity and work efficiency is to be surmounted, ways must be devisod to meet the demand for fish which far outstrips the supply from 1981-85 period till present as shown in Table 1.

Table 1 Demand, supply, gaps, and fish imports in Nigeria (1970-2000)

\begin{tabular}{llllll}
\hline \multicolumn{7}{c}{ ("000 Metric Tonnes) } & & \\
\hline reriod & Domestic Production & Domestic Consumption & Surplus & Imports** \\
\hline $1970-1974$ & 1769.65 & 1096.31 & +673.34 & 94.98 \\
$1975-1980$ & 2198.61 & 1353.22 & +845.39 & 682.98 \\
$1981-1985$ & 1403.86 & 1683.66 & -279.80 & 1141.08 \\
$1986-1990$ & 806.50 & 2019.37 & -1212.87 & 2014.89 \\
$1991-1995$ & 259.64 & 2263.84 & -2004.20 & N. A \\
$1996-2000$ & 599.83 & 2594.87 & -1995.04 & N.A \\
$2000-2005 *$ & 1012.86 & 2816.28 & -1803.42 & \\
$2006-2010^{*}$ & 1224.21 & 3016.67 & -1882.46 & \\
\hline
\end{tabular}

Source:Compiled from Annual Abstract of Statistics of the FOS (Various Issues)

*Indicates Projected Figures

**There is still importation in period of fish surplas because of the penchant of the high income class for elitist imported fish species.

The Table shows that while domestic fish production was declining, the deficil was widening and fish import increased considerably to make for the deficit. For instance, fish import, which was only 94.98 thousand metric tounes in 1970-74 had risen to 2014.89 thousand metric tonnes by $1986-90$ period. The implication of this is that a considerable proportion of our forcign exchange earnings is being allowed to drift to other countries of the world. Therefore, the need arises to explore all avenucs to increase and sustain fish supply in Nigeria. A right step in this direction will necessitate raising fish under controlled environment where their foeding, growh, reproduction and bealth can be closely monitored. Such artificial fish rearing method called aquaculture is already gaining wide popularity in Nigeria in general and Ondo State in particular (Mafimisebi, 1995) even though mostly at subsistence level. Only very few private coramercial fish farms are at present found in Nigeria. However, for rapid production of cheap animal proteins, increased number of private commercial fish farms is a welcome devclopment. This study therefore aims at determining the profitability or otherwise of private commercial fish ponds in the upland areas of the two riverine Local Government Areas (LGAs) in Ondo State. This is with the intention of drawing the attention of prospective investors to the potentials of aquaculture in the area. The specific research objectives includes an exploration of the opcrational and farm- specific characteristics of the samplod fish farms, a determination of the 


\section{Commercialised upland fish farming in Onde State}

cost and returns to investors in fish farms with a view to obtaining measures of profitability and efficiency of the aquacultural business and to determine the sensitivity of profitability to some costs and returns items.

\section{Materials and Methods}

This study was carried out in two purposively selected L.GAs in Ondo State. They are Ilaje and Ese-Odo LGAs. They were selected on the basis of being the earliest and largest fish production and marketing centres in the State. Twenty (20) private commercial upland lish farms were randonly selected from each of the two LGAs using as our sampling frame a list of private commercial fish farms in the area obtained from the Ondo State Agricultural Development Programme office.

A wcll-structured qucstionnaire was used to obtain information on the sampled fish farms and costs and returns of the production process for the production periods covering 1994-1998 The questionnaires were carlier pre-tested on the few private commercial fish farms in frele LGA of Ondo Statc, Only twenty-two (22) questionnaires were correctly completed and thus used in the analysis. The fixed costs incurred in the production process were calculated as annual costs or rental values of such fixed items. The depreciated cost (obtained through the straight-line method) represents an annual lost in value of the facilities and or equipment as a result of wear and tear arising from use. The cxpected usefui life (in years) of fixed itcms are as follows: Pond (20). Boat/canoe (8), Nets (5). Whoelbarrow (5), Bowls (5). Refrigerator / Decp Freezer (5), Generator (10), Outboard engine (8), Weighing scale (10), Farm building (25), Borehole and water pumps (8) Hatchery (10).

The data collected were analysed using descriptive statistics, which includes frequency counts. percentages and tables. The simple budget format analysis was used to determine profitability. The budget format analysis was first done for all the five years pooled together and then on a year by ycar basis. From the result of the analysis, certain ratios of profitability and efficiency were obtained. They
were:

$$
\begin{aligned}
& \text { 1. Operating Ratio }=\frac{T V C}{G R} \\
& \text { 2. Return on Sales }=\frac{\text { NP }}{G R} \\
& \text { 3. Return on Assets }=\frac{G M}{T C A}
\end{aligned}
$$

where

$$
\begin{aligned}
& \text { TVC = Total Variable Cost } \\
& \text { GR }=\text { Gross Revenue } \\
& \text { NP }=\text { Net Profit } \\
& \text { GM }=\text { Gross Margin } \\
& \text { TCA }=\text { Total Cost of Assets }
\end{aligned}
$$

The sensitivity analysis was carried out to ascertain the factors to which profitability is more responsive. The following profitability indicators were also used to measure the extent of returns from the aquacultural business.

(i)

Benefit - Cost Ratio: This is the ratio of discounted cosis to discounted revenuc. Mathematically, it is stated as:

$$
\mathrm{B} / \mathrm{C}=\frac{\sum_{t=T(T+r)^{n}}^{n} B t}{\sum_{t=1(t+r)^{n}}^{n} C t}
$$

where $\mathrm{Bt}=$ bencfit in each project year

$\mathrm{Ct}=$ cost in each project year

n $=$ number of ycars

$r$ - interest or discount rate

(ii) Net Present Value (NPV): The value today of a surphus that a project makes over and above what it would make by investing at its marginal rate. It is the value todiry of all streams of income which a project is to make in future. NPV is given as:

$$
N P V=\sum_{t=1}^{n} \frac{B t-C}{(1+r)^{n}} \text { where } B t, C t, n
$$

and $\mathrm{r}$ are as definced above.

(iii) Internal Rate of Return (IRR): It is the rate of return that is being expected on 
capital tied down after allowing for recoupment of the initial capital. It is also called the yicld of an investment. It is given by:

IRR =

Lower discount + Difference between rate the two chosen discount rates

$\left(\begin{array}{c}\text { NPV of lower discount factor } \\ \text { Absolute difference between the rwo NPVs }\end{array}\right)$

\section{Results and Discussion}

From the result. $77.3 \%$ of the apland farms have been in operation for less than ten vears. The implication of this is that the managers or owners of the farms are still relatively new it the business and may not have gatherod enough cxperience that can cnlauce productivity. The remaining $22.7 \%$ have operated for apwards of ten years. All the fish farms however staned as subsistence concerns before expansion to commercialized farms. Abon $63.5 \%$ of the managers of the fish farms have educational qualifications above primary sis ocrtificates while only $4.6 \%$ of then have certificatcs in agriculure, or related courses. None of the farm managers have a dogrec in fisheriss. The implication of this is that the technicalitics imolved in artificial fish rearing may not he known to these managers. This would definiteiy affect the level of profitability of the fish farms.

The total farm size of all the 22 fish farmis was $229.112 \mathrm{~m}^{2}$ (arca covered by fisi farm) while the total land area was $6.37800 \mathrm{~m}^{2}$. The total namber of fish pond units for the farms survejed was 123. The average size of a fish pond unit for all farms sumeyed was $1.863 \mathrm{~m}^{2}$. The modal fish pond size was $1901-2200 \mathrm{~m}^{2}$ and $35.78 \%$ of the obscrved farms fall within that range. The number of fish ponds with sizes lower than the average was $+5(36.59 \%)$ white $78(63.41 \%)$ had sizes greater than the average for all farms (Table 2).

Table 2 Distribution of fish ponds bv size $\left(\mathrm{m}^{2}\right)$



Source: Author's calcutation from survey data

The number of fish pond units on the 22 tarms suncyed varied from 1-10. Only two fish farms had one fish pond unit each whic only one farm inad 10 units of fish ponds. Majority (72.72\%) of the fish farms managed between $4-8$ fish pend units. Except in a few cases. the smalter the nuinber of fish pond units, the greater the total size of ponds on a farm and the greaticr the average sire per fisth pond (Table 3 ). 
Table 3 Distribution of fish farms by total size and number of ponds owned.

\begin{tabular}{llll}
\hline Fish Farms & $\begin{array}{l}\text { Total Sire Of Ponds } \\
\left(\mathrm{m}^{2}\right)\end{array}$ & Number of Ponds & $\begin{array}{l}\text { Average Sire* } \\
\left(\mathrm{m}^{2}\right)\end{array}$ \\
\hline 1 & 2669.37 & 5 & 533.87 \\
2 & 3003.04 & 6 & 500.51 \\
3 & 855.45 & 1 & 855.45 \\
4 & $19,186.09$ & 8 & 2398.26 \\
5 & 6006.08 & 3 & 2002.03 \\
6 & $13,513.68$ & 8 & 1689.21 \\
7 & 12.846 .34 & 8 & 1605.79 \\
8 & $26,693.70$ & 4 & 6673.42 \\
9 & 12.512 .67 & 6 & 2085.45 \\
10 & $26,026.35$ & 8 & 3253.29 \\
11 & $1,334.68$ & 2 & 667.34 \\
12 & $2,068.76$ & 1 & 2068.76 \\
13 & $3,003.04$ & 10 & 300.30 \\
14 & $18,769.01$ & 7 & 2681.29 \\
15 & $30,030.41$ & 4 & 7507.60 \\
16 & $3,378.42$ & 5 & 675.68 \\
17 & 6.673 .42 & 7 & 953.35 \\
18 & $3,003.04$ & 6 & 500.51 \\
19 & $8,008.11$ & 6 & 1334.69 \\
20 & $8,758.87$ & 8 & 1094.86 \\
21 & $12,012.16$ & 3 & 4004.05 \\
22 & $8,758.87$ & 7 & 1251.26 \\
& Total 229,112 & 123 & \\
\hline
\end{tabular}

Source: Feld Survey, 1998

*Compuled by author

About $95.5 \%$ of the fish farms are involved in table fish production. Fingerlings production is still not popular in the study area probably owing to the beavy outlay and technicalitics involved in running a hatchery. Majority of the fish farms source their fingerlings from the wild despite acknowledging discase infestation and high mortality rates in such locally procured seedstocks (Table 4).

Table 4 Distribution of upland fish farms by source of fingerlings

\begin{tabular}{lll}
\hline Source of Fingerlings/Fries & Frequency & Percentagc \\
\hline From wild & 16 & 72.73 \\
From own local hatchery & 1 & 4.55 \\
From other private hatcherics & 5 & 22.73 \\
Total & 22 & 100.00 \\
\hline
\end{tabular}

Source: Survey data, 1998.

Their reasons were that locally procured fingerlings were cheaper, readily available and timely supplied. Majority of the farms (68.2\%)

practise monoculture (i.c. rearing of one fish 


\section{Mafimisebi}

species in a pond unit). The managers of such farms believe that monoculture enhances fish growth rate due to absence of disturbance such as cannibalism and perking from other fish species. The managers of the farms using monoculture are also of the opinion that increased incidence of disease outbrcak is more rampant in polyculture. About $23.0 \%$ of the farms use polyculture becausc of financial and land constraints. Some of the farmers practising polyculture argue that the system reduces outlay on pond construction and maximizes returns from a pond unit especially when compatible species are cultured together. Only $7.0 \%$ of the farms employ both mono-and polyculture methods.

The fish species commonly cuilured in the upland parts of the study area are Tilapia, Alestes, Heterotis and Catfish. Not less than $40.9 \%$ of the twenty-two fish farmers rear these species on their farms. The other fish species which are reared but not so frequently are
Mudfish, Ifeterobranchus, Ophiocephatus. Aeroplane fish and Mormyrus. These species are reared by less than $27.3 \%$ of the sampled farms. The reasons given for preference for the first four species of fish were (1) case of procurement and high survival rates of fingerlings and fry (2) casy culturing (3) fast growth and reproductive rates (4) high yield and (5) high demand and price in the study area.
Analysis of Costs and Returns on a One- Hectare Upland Commercial Fish Farm (1994- I998)
The depreciated average fixed cost per bectare of fish farm was N517,591.48 in the five years studied. The depreciated cost of pond construction and vehicles and boats carried 10.47 and $11.75 \%$ of fixed cost respectively. Labour was the single most expensive item of fixed cost as it stood at $41.02 \%$. Table 5 shows the proportion of fixed cost acoounted for by other components.

Table 5 Fixed and variable costs for a one-hectare upland fish farm (1994-1998)

\begin{tabular}{llc}
\hline Fixed lterns & Cost $(\mathrm{N})$ & Pcroentage \\
\hline Land & $20,833.33$ & 4.03 \\
Pond construction & $54,166.67$ & 10.47 \\
Farm buildings & $23,257.33$ & 4.49 \\
Vehicles + Boats & $60,825.00$ & 11.75 \\
Nets & $11,395.83$ & 2.20 \\
Boreholes + Water pumps & $114,366.67$ & 22.10 \\
Wheelbarrow + basins & $5,999.67$ & 1.16 \\
Labour (permanent) & $212,333.33$ & 41.02 \\
Generators + Deep Freezers & $12,234.17$ & 2.36 \\
Local hatchery + Fencing materials & $2,179.17$ & 0.42 \\
\hline Sub-total & $517,591.48$ & 100.00 \\
\hline Fingerlings and Fry & $355,240.00$ & 17.30 \\
Fish feeds & $1,056,300.00$ & 51.44 \\
Fertilizers + other chemicals & $54,266.67$ & 2.64 \\
Transportation and fuel & $270,266.67$ & 13.16 \\
Repairs and maintenance & $188,466.67$ & 9.18 \\
Casual labour & $129,266.67$ & 6.29 \\
\hline Tolal & $2,053,806.68$ & 100.00 \\
\hline
\end{tabular}

Source: Survey data, 1998. 


\section{Commercialised upland fish farming in Ondo State}

The Table also reveals that seedstock constituted $17.30 \%$ of variable cost while fish feed (comprising fish pellets, spent grains, crayfish, some household left-overs, dried jumpers and bread) was the single most expensive item of variable cost accounting for $51.44 \%$ of total operating cost. Together, seedstock and fish feeds make up $68.74 \%$ of total variable cost. This finding is in accordance with that reported by Zadek (1984) and Inoni (1992) that the cost of feeds and secdstock accounted for more than $50.0 \%$ of total cost of production.

\section{Gross revenue (GR)}

Gross revenue is the amount realized from the sale of table fish, fingerlings and postfingerlings (jumpers). However only table fish production is prominent in the study area (Table 6).

The GR per hectare reported for the years studied was $7,371,586.00$.
Net Profit $=$ Total Revenue $(T R)-$ Total Cost (TC)

$=N 7,371,586.00-N(517,591.48+$

$2,053,806.68$ )

$=\mathrm{N} 7,371,586.00-\mathrm{N} 2,571,398.16$

$=\$ 4,800,187.84$ per hectare for five years.

The $\$ 4,800,187.84$ is the net revenue (NR) per hectare for the five years analysed. The average net profit per hectare per year is N960,037.57. Table 6 shows that Heterotis contributed the highest proportion of GR followed by Gymnarchus. Alestes ranked third. Ophiocephalus, Heterobranchus, Aeroplane fish and Mormyrus contributed about $1 / 15$ of GR. It can thus be concluded that Heterotis, Gymnarchus and Alestes are the major commercial fish species cultured in the study area.

Table 6 Gross revenue on a one-hectare upland fish farm.

\begin{tabular}{|c|c|c|c|c|c|c|}
\hline \multirow[b]{2}{*}{ Fish Species } & \multicolumn{6}{|c|}{ Gross Revenue Per Year $N(000)$. } \\
\hline & 1994 & 1995 & 1996 & 1997 & 1998 & $\begin{array}{l}\text { Total* } \\
1994-1998\end{array}$ \\
\hline Heterotis & 398.081 & 367.130 & 398.882 & 463.554 & 554.089 & $2,181.736$ \\
\hline Gymnarchus & 351.607 & 327.633 & 314.169 & 378.929 & 471.222 & $1,843.560$ \\
\hline Alestes & 266.747 & 215.363 & 142.851 & 321.713 & 346.238 & $1,292.912$ \\
\hline Tilapia & 121.205 & 97.043 & 93.174 & 109.859 & 112.912 & 534.193 \\
\hline Catfish & 107.316 & 76.690 & 86. 397 & 129.463 & 144.366 & 544.232 \\
\hline Heterobranchus & 99.110 & 62.258 & 69.587 & 106.828 & 135.846 & 473.629 \\
\hline Mudfish & 27.200 & 21.001 & 15.685 & 34.000 & 30.000 & 127.886 \\
\hline Ophiocephalus & 69.267 & 55.820 & 49.463 & 78.245 & 111.256 & 364.054 \\
\hline Mormyrus & 0.048 & 0.037 & 0.027 & 0.058 & 0.089 & 259 \\
\hline Total & $1,442.310$ & $1,224.225$ & $1,171.280$ & $\overline{1,625.064}$ & $1, \overline{908.707}$ & $7,371 . \overline{586}$ \\
\hline
\end{tabular}

*The total is actually unnecessary because of the problem of time value of money. However, they were given so that the budgetary analysis could be done.

\section{Profitability Ratios}

The year by year results of the budgetary analysis for a one-hectare fish farm is shown in Table 7. 
Table 7 Summary of year by year budyetary analysis of one thectare fish farm (1994-1998)

\begin{tabular}{|c|c|c|c|c|}
\hline Year & $\begin{array}{l}\text { Total Variabie Cost } \\
\text { (TVC) (N) }\end{array}$ & $\begin{array}{l}\text { Gross Revenue } \\
(\mathrm{GR})(\mathrm{N})\end{array}$ & 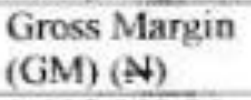 & $\begin{array}{l}\text { Net Profit (NP) } \\
\text { (A) }\end{array}$ \\
\hline 199.4 & 326.311 .76 & $1.442,310.00$ & $1.115,998.24$ & $1,012.479 .94$ \\
\hline 1995 & $401,843.77$ & $1.224,225,00$ & 822.381 .23 & $718.862,93$ \\
\hline 1996 & 452.761 .09 & $1,171,280,00$ & 718.518 .91 & $615,000.61$ \\
\hline 1997 & 341.08284 & 1.625 .064 .00 & $1.283,981,16$ & $1.180,462.86$ \\
\hline 1998 & 531.787 .21 & 1.908 .707 .00 & $1.376,919.79$ & 1.165 .883 .19 \\
\hline
\end{tabular}

Source: Author's Calculation from Survey Data

From the yaiues given in the Tatok. profinability ratios were calculated and these enabled a conclusion to be made as to the efficiency of fish farms in the years studied. A decreasing operating ratio over time is an indication of a good and efficient business. Table 8 shows the profitability ratio of one hectare fish farm by year.

Table 8 Profitability ratios of one - hectare fish farm by year (1994-1998)

\begin{tabular}{llll}
\hline Ycar & Opcrating Ratio & Reiurn on Sales & Return on Assets \\
\hline 1994 & 0.226 & 0.702 & 2.156 \\
1995 & 0.328 & 0.587 & 1.589 \\
1996 & 0.387 & 0.525 & 1.388 \\
1997 & 0.210 & 0.726 & 2.481 \\
1998 & 0279 & 0.611 & 2660 \\
\hline
\end{tabular}

Source: Author's calculation from survey data

A decreasing operating ratio in this study signifies either increasing TR or decreasing TVC. Operating ratio was 0.226 in 1994 but assumed an increasing trend to 0.328 and 0.387 respectively in 1995 and 1996 . Operating ratio was lowest in 1997 at 0.210 followed by 0.279 in 1998 . The fluctuating trend in operating ratio is not a desirable situation in the fish farms. The fish farmers must do all that is possibie to achieve a consistently decreasing operating ratio. This can be achicved by preventing waste and over-feeding of fish beyond a stipulated marketable weight and exploring avenucs for wider market outlets. Each of these scenarios will lead to either a decreaise in TVC or an increase in TR which will bring down operating ratio.

An increasing return on sales ov cr tume indisates a stable. profitable and efriciem business. Return on sales was highest in $1 \mathrm{yy}^{-}$followed by 1994. Low values were achisu ed ite: this index in 1995 and 1996 while the 1998 value ef 0.611 falls below the 1997 value of 0.720 . Fish farmers need to take more steps to m.ke sure that retum on sale is increasing or at liast keps constant. The return on assets wlin. w, is $\geq 1.54$ in 1994 reduced to 1.589 and $1.38 \times$ in $1995,1: 2$ 1996 respectively. The ycars with the best return on assets were 1998 and 1047 in the. order). An increasing return on asset mdisates that assets are being more intensively ufihued and so the farmers must seck to achieve this. One way of doing the is to leuse out to other farms some fixed assets which are erity uscful at specific time of the year. Flas cyrapsictet leasing will lead to more inkwss. Instgation of asscts and increasing reveno: whoch will resulf in increasing retum on siles.

Judging by these three profitabilisy and efficiency ratios, 1997 is the best year of performance by the fish farms followed by 1998 and 1994. The year 1996 recorded the poorest 


\section{Commercialised upland fish farming in Ondo State}

performance. Taking these ratios together however, the result of the study permits the conclusion that aquacultural business is a fairly stable and efficient venture in the study area.

Cash Flow and Sensitivity Analysis analyses are as follows:

1. The average bank-lending rate to agriculture in the twelve years covered by the sensitivity analysis is $25 \%$

2. A risk-discounted factor of $5 \%$ is added to the bank-lending rate. This means hat a $30 \%$ discount factor is used.
3. There is a 20 and $10 \%$ projected yearly increase in variable cost and unit fish price between 1999-2010. This is in accordance with the farm management maxim, which says it is better to allow costs to rise faster than revenue in the estimation of fature profitability of a venture (Adegeye and Dittoh, 1985).

4. Lan repayment was made in equal installment starting from the end of the first year of project life.

The result of the cash flow and sensitivity analysis is shown in Table 9. 


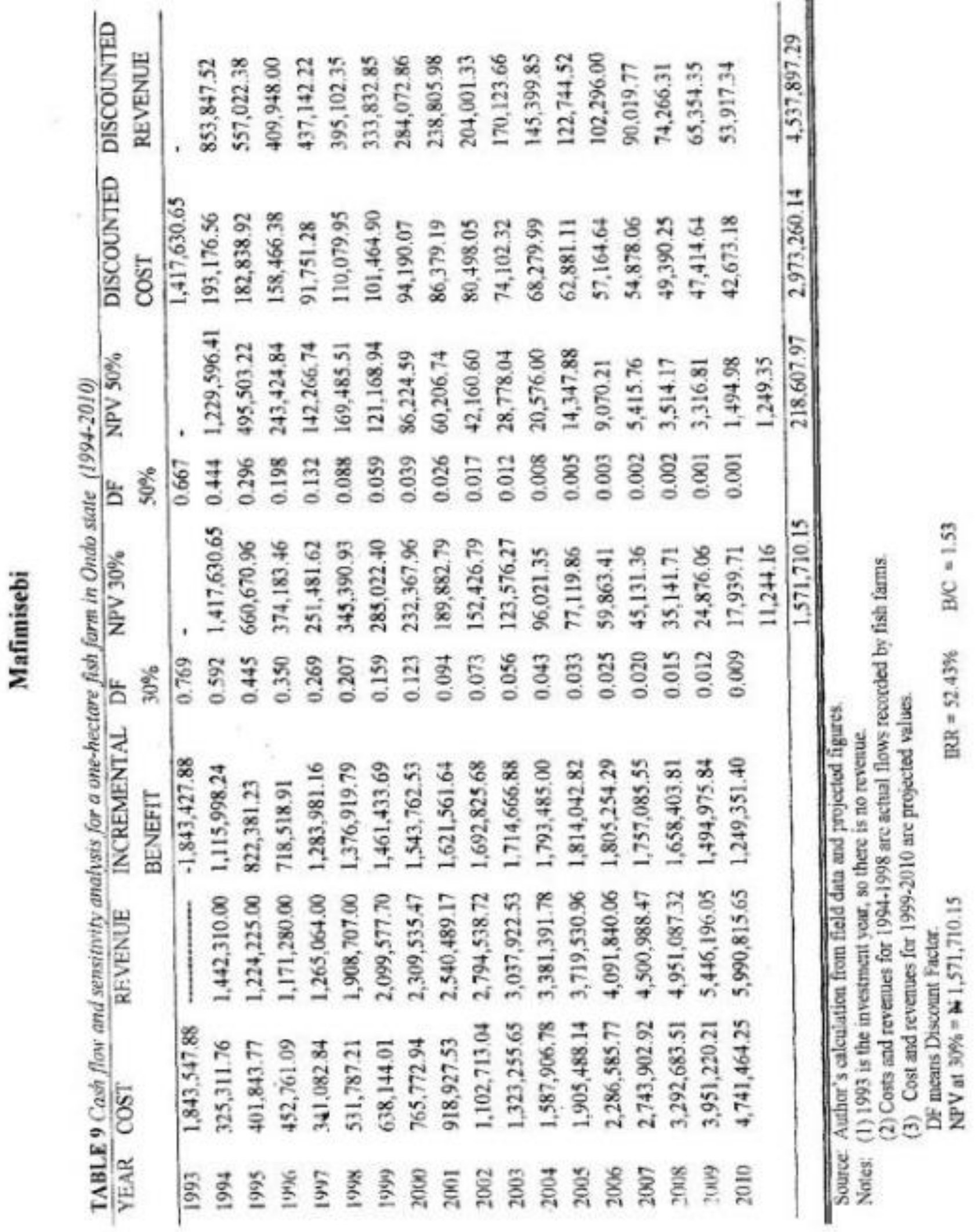

สุ 
The sensitivity analysis carried out indicates profitability of the aquacultural venture despite increases in prices of key production inputs. For $\mathrm{B} / \mathrm{C}$ stood at is was $\mathrm{N} 1,571,710.15$ while the IRR is commendable because $52.43 \%$. The lending rate of $25 \%$, the invester at the bank cvery N100 invested as returns gets $\mathrm{N} 27.43$ on The results also indicate that management. more responsive to changes in unit price of is This information is critical for the stustainability of the business in the long ran.

\section{Opportunity Cost of Invested Capital}

The earnings which the invested capital should have made if simply lodged in a bank was in upland aquaculthe profit made from investment per hectare for the totat amount invested N2.571.398.16. year was $\mathrm{N} 4,800,187.84$. This after the fifth $187.4 \%$ returns to investor had lodged the moncy if if the account with the assumption that in savings accruing is being withdrawn for spending at the end of every year, then, at the average bank interest rate of $25 \%$ betwoen 1994-1998, the total interest accraing to the investor would be amounts to $63 \%$ at the end of the fifth year. This analysis shows that invest in aquactiture is far more profitable to bank.

\section{Constraints to Upland Fish Farming}

The problems commonly encouaterod in upland terms of number of farms area were ranked in problem out of the 22 farms sarvered that problems are (1) Financiat cos sarveycd. The (2) high running cost $(86.4 \%)$, doing $(95.5 \%)$. ponds due to secpage of water through up of $(63.6 \%)$, mass loss of fish due to nse of dykes or high temperature water $(63.6 \%)$. scarcity of seekstocks $(59.1 \%)$ and incidence of pests and are therefore fine Thost frequent problems after meeting the triet constraints which arisc after meeting the trigh outlay on ixed cosi and running cost of the enterprise. Other problems are also important even though they appear less frequent than the first two. For example, thicves can harvest a fish pond at night exocpt security is tight around the fish farm. This has resulted into a huge loss of investment by some farms.

\section{Conclusion and Recommendations}

The study has made antempt to explore the socio-economic and operational characteristics of upland fish farms, estimated the profitability of investuncent in fish farming and determined the production variables to which profitability is more sensitive. In addition. the study has also examined the constraints to fish production in the area stadied

From the study, /eterotis niloticus, Gymnarchus niloticus and Alestes baramose contributed the grealest proportion to gross revenue. They are therefore the commercial fish species cultured in the upland parts of the study arca. The fixed cost per hoctare of fish farm for the period studied was, $\mathbb{4} 17.591 .48$ while variable cost stood at A $2,053,806.68$. The most important items of fixed cost were labout $(41.02 \%)$, borehole and watcr pump $(22.10 \%)$, land and pond construction $(14,50 \%)$. in variablc cost. the most important components are fish feeds $(51.44 \%)$, secdstock (17.30\%). and Iransportation and fucl $(13.16 \%)$

Various profitability ratios showed that upland aquaculture is a worthwhile business in the area studicd. However, there is the need for farmers and profitability of the the trend of efficiency indicated by the rates aquacultural business as carricd but the ratios. A sensitivity analysis responsive to the price of profitability is more the cost of inputs. The ability of the imyestors with sustain the retarns from the aquacultural business will then be dependent on the relative prices of inputs and output. The results demonstrate that fish farning is a very profitable business even at an interest rate of $30 \%$ in the arca. The studs shows that there is a $37.48 \%$ yeariy returns to capizis investod in aquacuiture 


\section{Mafimisebi}

compared whth a $21.0 \%$ ycarly alternative returns to capital if money is lodged in a savings accounts

It is recommended that the government makes access to land and investible funds (at bearable interest rates) to fish farmers a priority in the study area. The cost of feeds should also be subsidized. The Ondo State Agricultural Developnent Programme (ADP) or the Federal Department of Fisheries should help establish a modern hatchery in the study area where seedstocks can be produced and sold to practising fish farmers. If the government agencies play these roles suggested, then, the fish farmers in the study area would definitely become and remain partners in progress with the federal government in her quest for increased. readily available and affordable animal proteins in Nigeria.

\section{References}

Adegeye. A. J. and Dittoh, J. S. 1985. Essentials of Aericultural Economics. Impact Publishers Nigeria Limited. Ibadan.

Adewale, A.S. 1985. Production. Marketing and the Consumption of Fish in Oyo State, Nigeria. Unpublished BSc project, Department of Agricultural Economics, University of Ibadan.

Geoff, A., and Bennet, C.J. 1995. Fish Mammies and Tuna Conglomerates; Private Sector Fish Processing and Marketing in Ghana In Marketing Africa's Ihigh - Value Foodv (eds) Steven. J, and John, M. Pg 375-416.
Inoni, O.E. 1992. Financial Analysis of Fish Farming in Delta State of Nigeria. Unpublished M.Sc thesis, University of Ibadan.

Mafimisebi, T.E. 1995, Yield Performance of Selected Fish Ponds in Ilaje Esc-Odo LGA of Ondo State. Unpublishod M.Sc thesis. University of Ibadan.

Olayemi, J.K. 1996. Food Security in Nigeria. The Report of a Research Study Sponsored by Development Policy Centre, Ibadan, Nigeria

Olayide, S.O; O. Ogunfowara, S.M. Essang and F.S. Idachaba. 1981, Elements of Raral Ficonomics, Pg 130.

Sadek, S. 1984. Development de I' aquaculture en Egypt. Reference $a^{\prime}$ la farme de Reswa (Port Said - et proposition d'une politique mationale equacole, Institute National Polytechnique de Toulouse, Ph.D thesis. $\mathrm{Pg} 151$.

Tobor, J.G. 1990. The Fishing Industry in Nigcria: Status and Potentials for Self Sufficiency in Fish Production NIOMR Technical Paper No. 54, pg I-2.3.

World Bank, 1996. Nigeria, Poverty in the Midst of Plenty. The Challenge of Growth with Inclusion. A World Bank Poverty Assessment Report No. 14733 UNI May 31.

(Recervidt 2 Fobruary 2002: Accepted 26 September 2002) 